\title{
Therapeutical evaluation of Turda Salt Mine microclimate on pulmonary fibroblasts cultures
}

\author{
- Constantin Munteanu ${ }^{1}$, Diana Munteanu, Iuri Simionca, Mihai Hoteteu, Ovidiu Mera
}

\section{Abstract}

Objective: To investigate the influence of salt mine medium from the Turda Salt Mine upon the cell morphology and electrophoretic expression of pulmonary fibroblasts in vitro obtained from Wistar rats' lung, in normal and Ovalbumin challenged - "asthmatic" conditions.

Materials and methods: Pulmonary fibroblasts cultures were prepared from Wistar rat lung. Cultures derived from lung rat develop with a monolayer of fibroblasts attached to the culture dish. Before cultures initiation, Wistar rats of 75-100 g weight were divided in two lots: control and ovalbumin challenged animals. Five animals of each lot were send to Turda Salt Mine for 14 days and maintained in the salt mine medium, as in speleotherapy treatment.

Results: Speleotherapy of Wistar rats had induced significant differences in cell morphology and electrophoretic expression of primary pulmonary fibroblasts cultures. The data obtained support the protective effects of speleotherapy by comparing with ovalbumin sensibilised animals.

Conclusions: The results of this study indicate the fact that speleotherapy induces changes on the morphology and protein expression of pulmonary fibroblasts in vitro, and these changes support the therapeutical properties of Turda Salt Mine medium.

Key words: speleotherapy, fibroblasts, salt mine.

\footnotetext{
${ }^{1}$ Corresponding author: Constantin Munteanu, tel./fax: +40213186458, e-mail: constantin2378@yahoo.com, mailing address: B-dul Ion Mihalache, nr.11A, District 1, cod 79173, Bucharest, Romania, http://www.cell-culture.xhost.ro/
} 


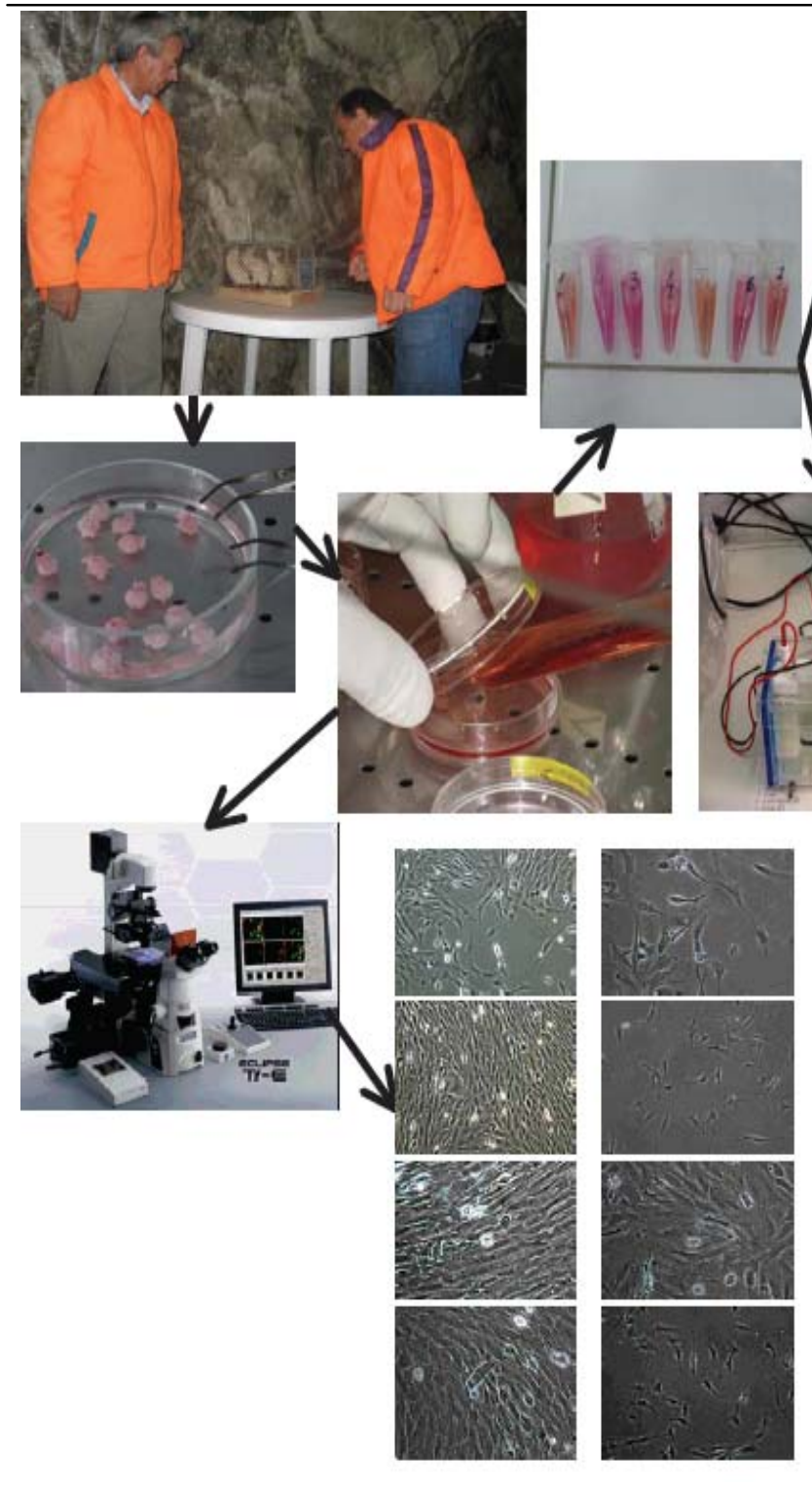

\section{INTRODUCTON}

Asthma is a disorder characterized by chronic inflammation of the airways, airways hyper-responsiveness, and changes in airway architecture, termed remodeling. The cells responsible for maintenance of lung structure are the parenchymal cells of the lung, including epithelial cells, mesenchymal cells, and endothelial cells. Recent studies have suggested that the function of epithelial cells, smooth muscle cells, and fibroblasts cultured from lungs of individuals with asthma differs from the function of cells similarly cultured from individuals without asthma. These functional differences, particularly as they relate to repair and remodeling, could contribute airway structural alterations (Sugiura et al., 2007).

The current study was designed to investigate the influence of salt mine medium

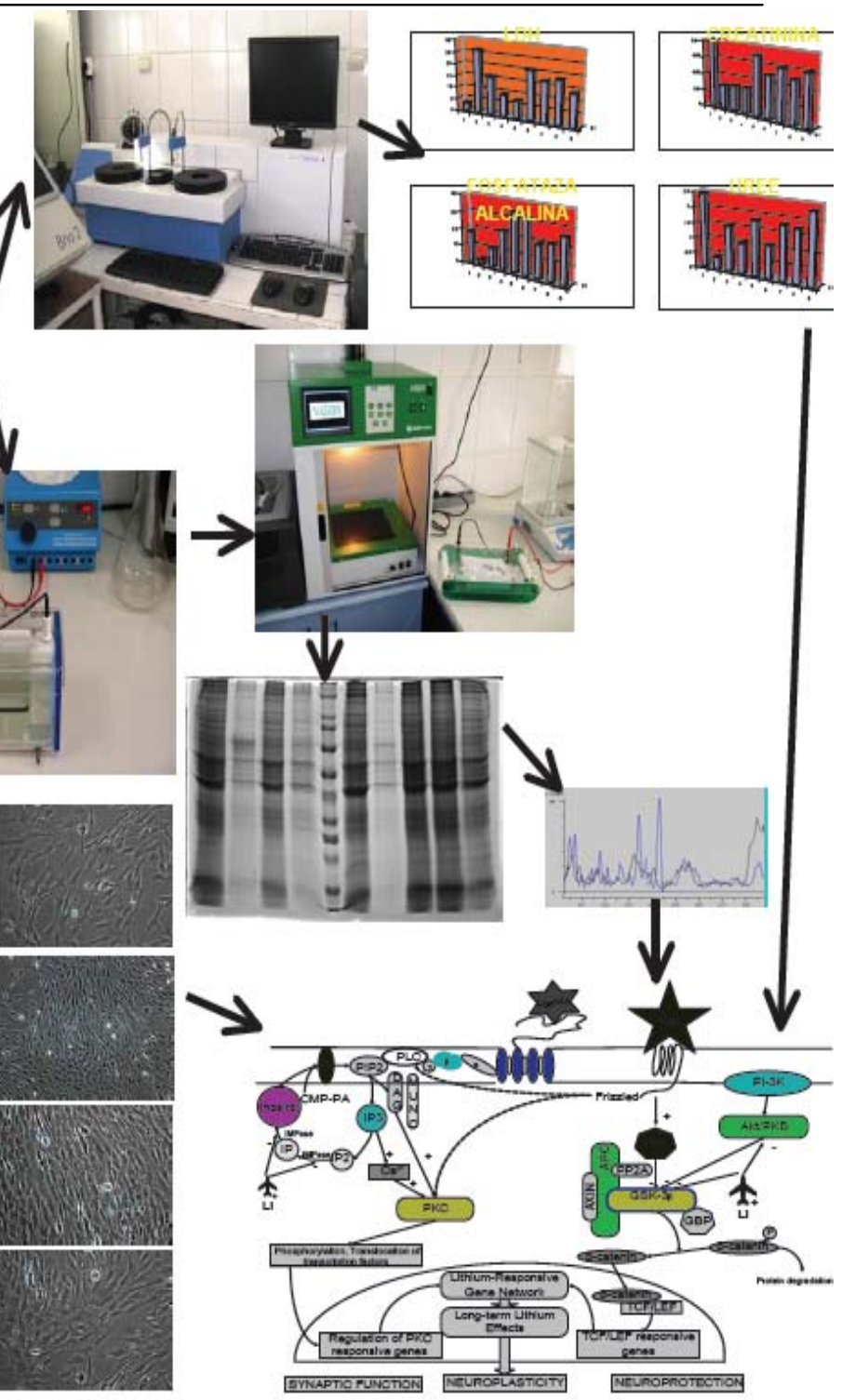

from Turda Salt Mine upon the cell morphology and electrophoretic expression of pulmonary fibroblasts in vitro obtained from Wistar rats' lung, in normal and Ovalbumin challenged "asthmatic" conditions.

Fibroblasts were cultured from lung parenchyma of control, ovalbumin-sensitized, and speleotherapy treated rats after ovalbuminsensitization. Fibroblasts shape in culture can vary in accordance with the substrate, which on they is growing, and the space they have for movement.

Using pulmonary fibroblasts cultures to verify the therapeutic properties of Turda Salt Mine medium, described as speleotherapy, represents an innovative and scientific way to establish the medical methodology of preventing, treating and recovery of patients with various pulmonary problems. 


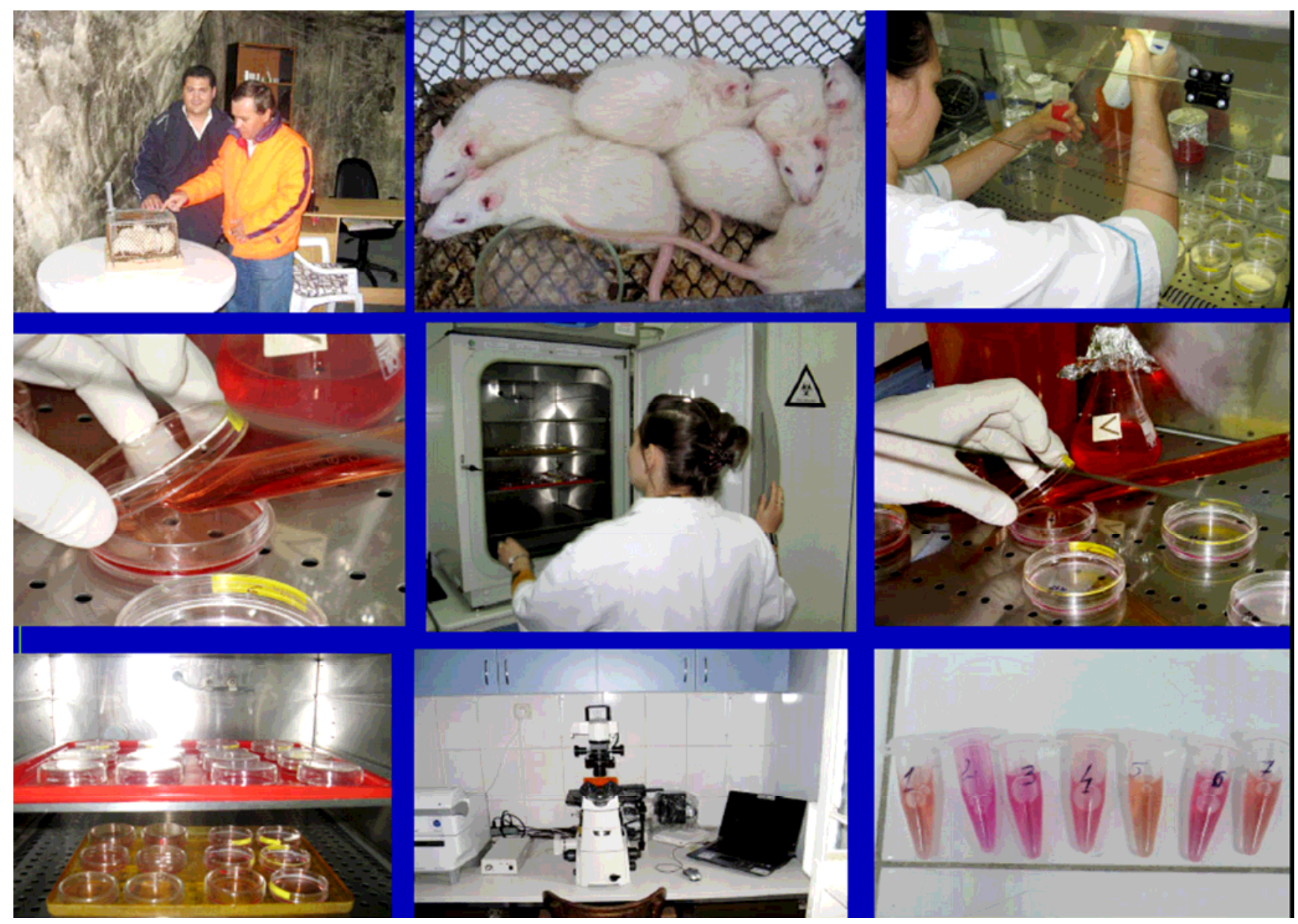

\section{MATERIALS AND METHODS}

\section{Materials}

Phosphate Buffer Solution (PBS: $\mathrm{NaCl}$ $0,13 \mathrm{M}+\mathrm{KCl} 2,6 \mathrm{mM}+\mathrm{Na}_{2} \mathrm{HPO}_{4} \times 12 \mathrm{H}_{2} \mathrm{O}$ $\left.8 \mathrm{mM}+\mathrm{KH}_{2} \mathrm{PO}_{4} 1,4 \mathrm{mM}\right) ;$ HAM-F12 culture medium (Sigma); penicillin $100 \mathrm{U} / \mathrm{ml}$, streptomycin $100 \mu \mathrm{g} / \mathrm{ml}$; neomycin $50 \mu \mathrm{g} / \mathrm{ml}$ (Sigma); fetal bovine serum (Sigma).

Rat Wistar Model of Allergic Asthma Wistar rats of $75-100 \mathrm{~g}$ weights were sensitised to Ovalbumin by i.m. injections.

\section{Primary fibroblasts culture}

After anaesthesia with chloroform, rats were killed. The thorax was opened and then the lungs were removed en bloc in a laminar flow hood using sterile technique and put into ice-cold sterile Phosphate Buffer Solution (PBS: $\mathrm{NaCl} 0,13 \mathrm{M}+\mathrm{KCl} 2,6 \mathrm{mM}+\mathrm{Na}_{2} \mathrm{HPO}_{4}$ $\left.\mathrm{x} 12 \mathrm{H}_{2} \mathrm{O} 8 \mathrm{mM}+\mathrm{KH}_{2} \mathrm{PO}_{4} 1,4 \mathrm{mM}\right) .1 \mathrm{~mm}$ tissue pieces were suspended in $0.125 \%$ trypsin and $0.001 \%$ DNase and repeatedly stirred for 6 minutes and centrifuged at $1000 \mathrm{~g}$. The pellet was resuspended in HAM-F12 medium with 4500mg/l glucose, $25 \mathrm{mM}$ HEPES, $100 \mathrm{U} / \mathrm{ml}$ penicillin, $100 \mu \mathrm{g} / \mathrm{ml}$ streptomycin and 50 $\mu \mathrm{g} / \mathrm{ml}$ neomycin and $10 \%$ fetal bovine serum
(Sugiura et al, 2007; Foster et al, 1990; Nunez et al, 1995).

\section{Phase Contrast Microscopy}

Phase contrast microscopy, first described in 1934 by Dutch physicist Frits Zernike, is a contrast-enhancing optical technique that can be utilized to produce high-

contrast images of transparent specimens, such as living cells.

\section{SDS-PAGE Electrophoresis}

The proteins electrophoresis from the total homogenate has as the purpose to establish the changes, which are revealed at the proteic level of fibroblasts cultures obtained from rats held on Turda Saline Mine medium for the speleotherapy.

The proteins electrophoresis in gel of polyacrylamide was done in the denaturated conditions in the conformity with the techniques described by Laemmli (1979). The cultures have been washed with PBS, curetted from the culture plate and lyzed in buffer containing $0,5 \mathrm{M}$ Tris- $\mathrm{HCl}, \mathrm{pH} 6,8+0,05 \%$ $\mathrm{BPB}+10 \%$ glycerol + SDS $10 \%$. 

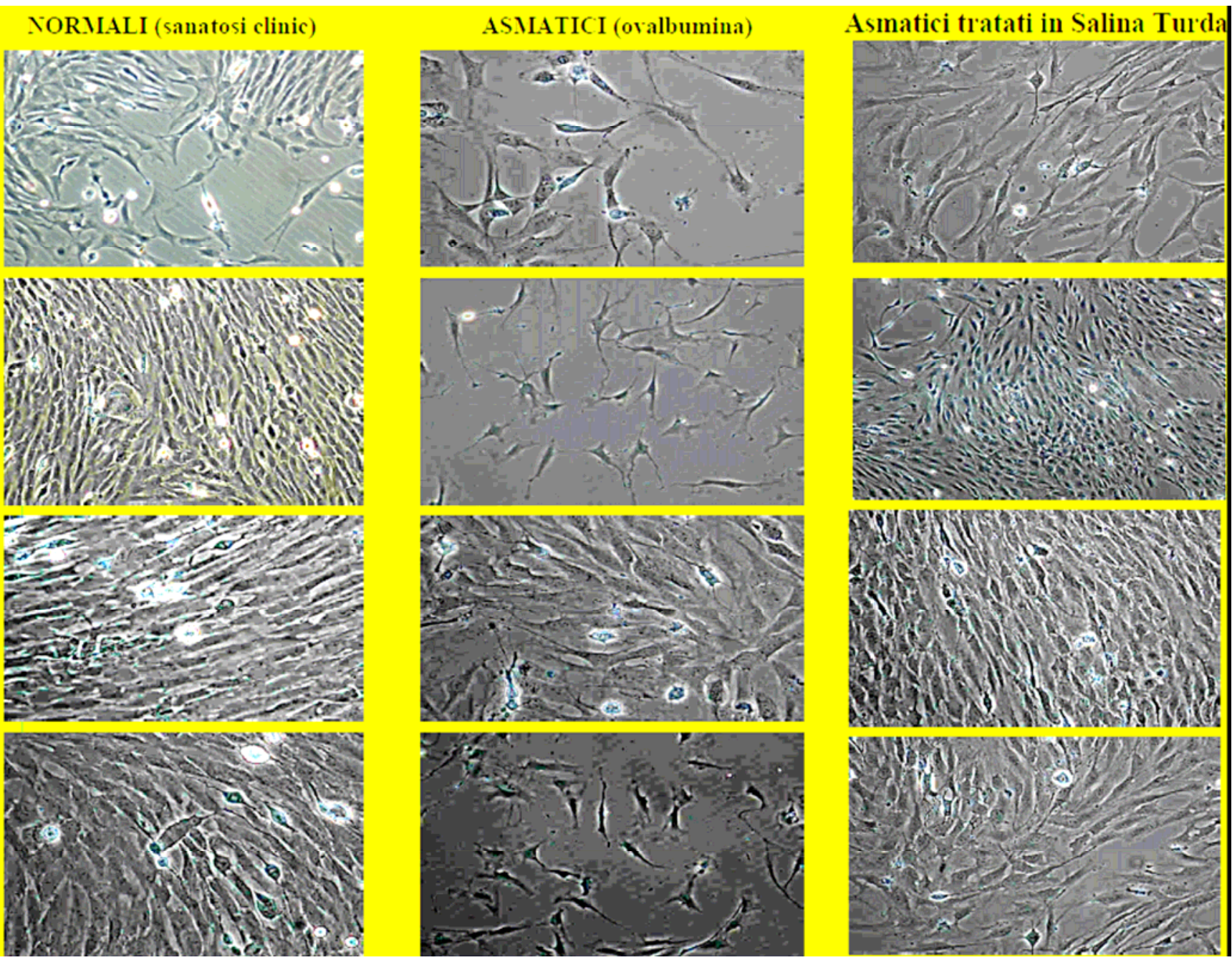

\section{RESULTS}

Control pulmonary fibroblasts culture of 7 days has a homogenic aspect with a high preconfluence level. The cell division is to a high level and the cell morphology shows a typical microscopic view, described in the specific literature.

Pulmonary fibroblasts cultures of 7 days obtained from Ovalbumin sensitised rats presents many morphological changes from the control pulmonary fibroblasts culture, being observed an sensible number reducing of pulmonary fibroblasts in culture, the diminished cellular dividing frequency and an accentuated cellular morphopathology of the cells in culture. After 7 days of culturing, the pre-confluence level is much lower than in the control case.

Pulmonary fibroblasts cultures of 7 days obtained from Ovalbumin sensitised rats and treated by speleotherapy in Turda Salt Mine shows an improvement of the morphological parameters of the cells comparative with the cultures obtained from Ovalbumin-challenged asthmatic rats.

Pulmonary fibroblasts were homogenized with Laemmli buffer $\mathrm{pH}$ 6,8, and the proteins of the obtained homogenate were separated by $10 \%$ SDS polyacrylamide gel electrophoresis that maintains polypeptides in a denatured state once they have been treated with strong reducing agents to remove secondary and tertiary structure.

Samples of $10 \mu 1$ were loaded into wells in the gel. One lane was reserved for Sigma molecular markers mixture of $205 ; 116 ; 97 ; 66$; $55 ; 45 ; 36 ; 29 ; 24 ; 20 ; 14,2$ and $6,5 \mathrm{KDa}$

Following electrophoresis, the gel was stained with Coomassie Brilliant Blue R-250, that allowed visualization of the separated proteins. After staining, different proteins appeared as distinct bands within the gel (Towbin et al., 1979). 

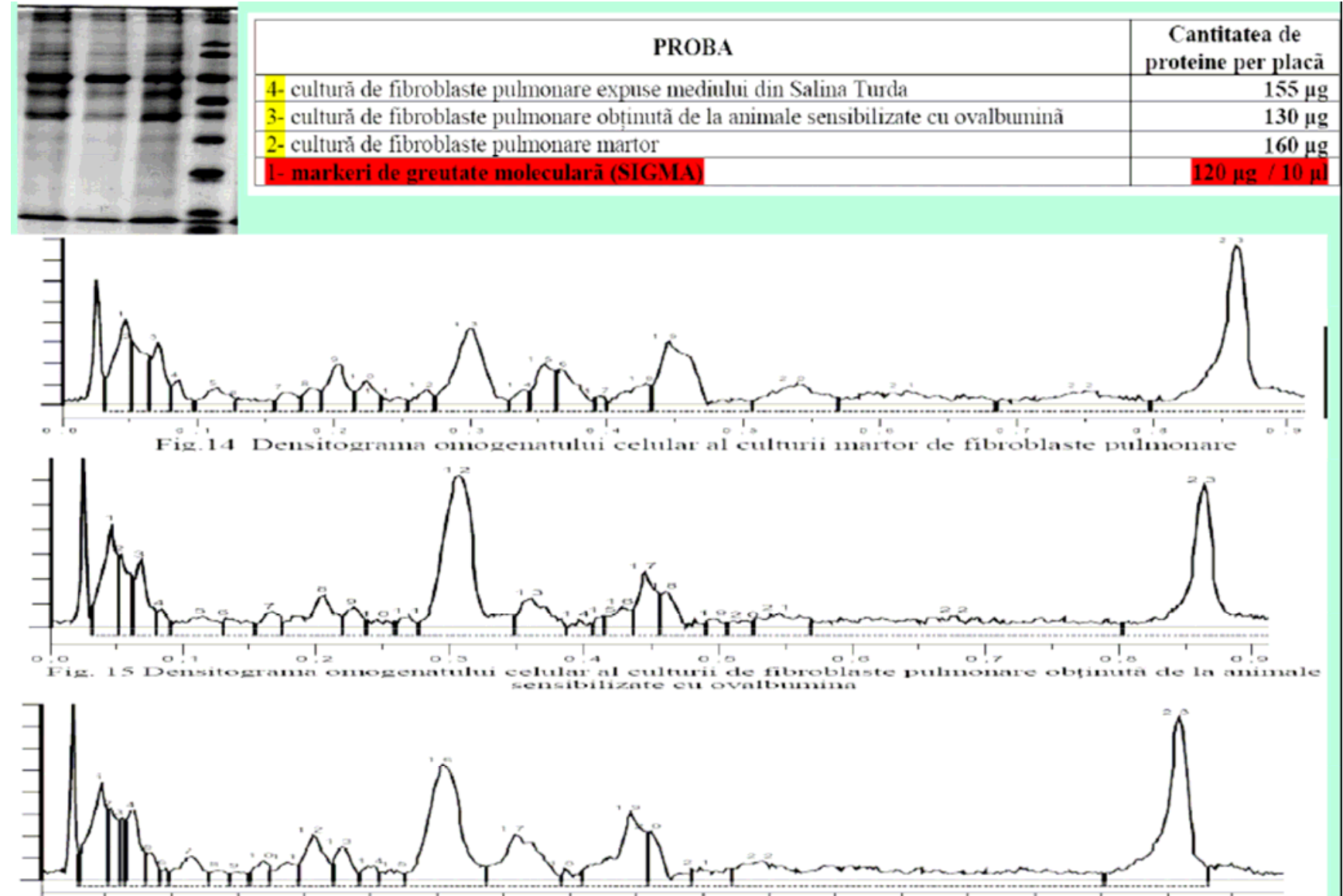

semsibilisate si expme mediundin Solina Tuma

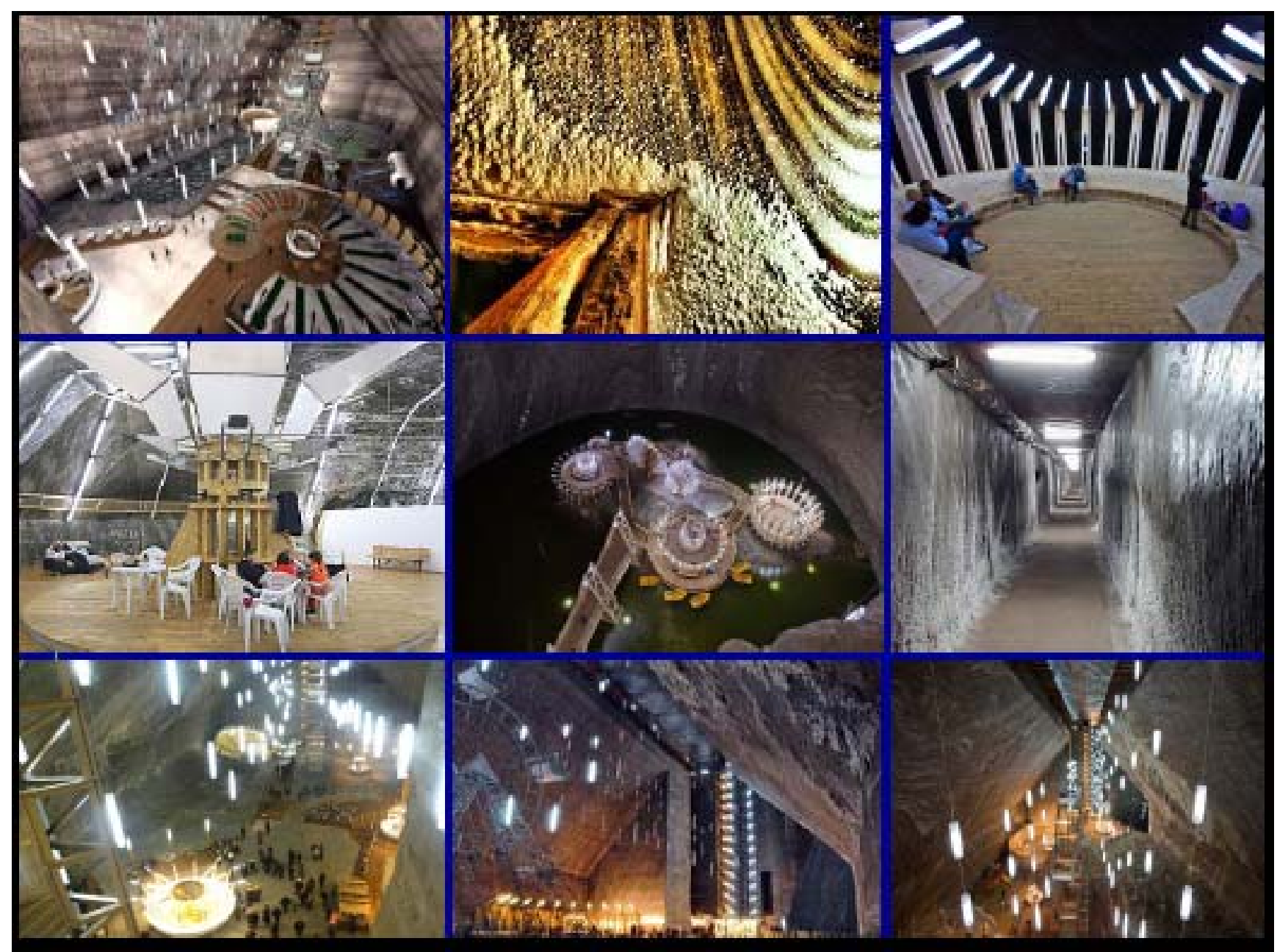


Analysis with GeneTools version 4 software from SynGene of each track of the electrophoresis, allowed us to compare the profiles of the total proteins expression.

The data obtained confirm our observations of optical microscopy, was detected a lower level of $130 \mu \mathrm{g}$ total protein from induced asthma for as against $160 \mathrm{mg}$ in control. Speleotherapy cure in Turda Salt Mine restored this parameter to a value close to control, ie $155 \mathrm{mg}$ total protein.

\section{CONCLUSIONS}

Microscopy analyses of primary fibroblasts cultures reveal a cellular regeneration after animal exposure to saline medium in Turda Salt Mine, comparative with the cells morphology of cultures from Ovalbumin sensitized rats.

The morphological observations are confirmed by the electrophoretic analyses, which demonstrate through rising of the expression of many proteins and of total protein amount that the exposure of Ovalbumin-sensitized animals to the saline medium from Turda Salt Mine is reversing the cells morphopathology of pulmonary fibroblasts in cultures;

\section{DISCUSSION}

The present study evaluated morphological phenotypes related to repair and remodeling in fibroblasts obtained from control Wistar rats and from Ovalbumin-sensitized and -challenged rats, a model of asthma that results in airway hyperresponsiveness and chronic airway remodeling, as other authors had presented.

Compared with control fibroblasts, fibroblasts obtained from lung parenchyma of the "asthmatic" rats and Ovalbumin-sensitized rats treated in Turda Salt Mine demonstrated the positive role of the saline medium for the "asthmatic" rats.

The current study focused on fibroblasts, which are believed to be cells that play a major role in the maintenance and remodeling of interstitial connective tissue. In this context, fibroblasts are believed to play a key role in maintaining and altering tissue structure. The ability of fibroblasts to migrate in response to chemotactic stimuli and to proliferate in response to specific growth factors is believed to control their accumulation at sites undergoing tissue repair. The ability of fibroblasts to produce and remodel extracellular matrix is thought to contribute to tissue structural changes. Remodeling of tissues likely involves fibroblast contractile activity.

In summary, the present study supports the concept that phenotypically altered fibroblasts can contribute to airway remodeling in asthma. Fibroblasts cultured from the lungs of chronically OVA-sensitized and -challenged animals demonstrated consistently augmented repair responses for a number of functional assays (Sugiura et al., 2007).

\section{Acknowledgments}

This study was funded by contract nr. $\mathbf{5 3 6 6}$ bis./2010 with SC Turda Salina Durgãu SA, as the beneficiary of the results.

\section{References}

1. Foster Judith Ann, Celeste B.R., Miller M.F. - Pulmonary Fibroblasts: an in Vitro Model for Emphysema, The Journal of Biological Chemistry, Vol. 265, No. 26, 1990, p. 15544-15549;

2. Laemmli U.K. (1979) Cleavage and structural proteins duting the assembly of the head of bacteriophage $\mathrm{T}_{4}$. Nature 227: 680-682.

3. Nunez J.S., Torday J.S. - The Developing Rat Lung Fibroblast and Alveolar Type II Cell Activity Recruit Surfactant Phospholipid Substrate, American Institute of Nutrition, 1995, 1639S-1643S.

4. Towbin H., Staehelin T., Gordon J. (1979) Electrophoretic transfer of proteins from polyacrylamide gels to nitrocellulose sheets: Procedure and some applications. Proc. Natl. Acad. Sci. USA 76: 4350-4354.

5. Simionca I., Grudnicki N., Buturuga A., Hoteteu M., Kiss J., Oprina A. Speleoterapia bolnavilor cu astm bronşic non-sever prin intermediul factorilor terapeutici din salina Slãnic Prahova, Editura "George Tofan", Suceava 2009, ISBN 978-973-1862-87-3

6. Sugiura H., Liu X., Duan F., Kawasaki S., Togo S., Kamio K., Wang X.Q., Mao 1., Ahn Y., Ertl R.F., Bargar T.W., Berro A., Casale T.B. - Cultured Lung Fibroblasts from Ovalbumin-Challenged "Asthmatic" Mice Differ Functionally from Normal, Am. J. Respir Cell Mol Biol, Vol 37, pp 424430, 2007 